\title{
Hate Speech: The Phenomenon of Offensive Language
}

\author{
Rahmadsyah Rangkuti, Zulfan, and Andi Pratama Lubis \\ University of Sumatera Utara, Medan, Indonesia
}

\section{Abstract}

A characteristic inherent in a democratic State is a guarantee of freedom of opinion and expression by every citizen. However, the space for freedom cannot be misused to express various ideas or views so that it becomes a tool to attack human rights and the freedom of others manifested in the form of hate speech. Acts of hate speech are currently getting more and more attention from various circles, not only for law enforcers and practitioners, politicians, information and communication technology experts. But it is also a very serious concern for the Indonesian government to form and give birth to regulations concerning to handling of hate speech. Moreover, caring for diversity and harmonization in diversity in the era of globalization of information

Corresponding Author: Rahmadsyah Rangkuti rangkuti@usu.ac.id

Received: 1 July 2019

Accepted: 18 July 2019

Published: 31 July 2019

Publishing services provided by Knowledge E

(c) Rahmadsyah Rangkuti

et al. This article is distributed

under the terms of the

commons Attribution License,

which permits unrestricted use and redistribution provided that the original author and source are credited.

Selection and Peer-review under the responsibility of the AICLL 2019 Conference Committee.

\section{G OPEN ACCESS} technology is the biggest challenge today. In this study, phenomenology is used as research design whereas purposive sampling from online media is used to collect the data. The aim is to maintain unity in the midst of a multicultural community life such as Batu Bara. On the other hand, the emergence of discussions about hate speech actually gave the object of a new study for linguistics. Based on the linguistic perspective, hate speech is a phenomenon of offensive language that can present linguistic data and can be analyzed linguistically. Therefore, this article conceptually describes the role of linguistics and linguists in understanding and explaining the subject of hate speech.

Keywords: Hate speech, speech acts, offensive, language

\section{Introduction}

A democratic country like Indonesia has several characteristics including guaranteeing freedom of expression and opinion for every citizen. It is regulated in the constitution of article 28 paragraph (2) and paragraph (3) which guarantees the right of every person to express their thoughts and attitudes according to their conscience and the right to issue opinions. Even so, according to Rongiyati (2015) freedom is still to be limited given that Indonesia is a country that has a diversity of cultures, customs and beliefs. Therefore, according to him, Indonesia's biggest challenge is managing and anticipating acts of hate speech. The inability of the State to anticipate and overcome acts of hate speech can provide an opportunity for the transformation of a number of hardliners to divert 
the arena of struggle from "war with firearms" to "war with words" (Ahnaf and Suhadi, 2015).

Hate speeches do not only occur in Indonesia, according to Sihombing, et al (2012) the act of utterance of hatred and blasphemy of religion also occurs in various European countries, Jordan, Egypt and Pakistan (read also Goldberg, 2015; Townsend; 2014; Ezeibe and Ikeanyibe; Imparsial, 2017). Even quoting Teja (2017), case of hate speech also occurred in India and the United Arab Emirates.

UNESCO as a United Nations (UN) organization defines hate speech (Gagliardon, 2015), as a message of hatred that reflects an expression of incitement to harm (specifically discrimination, hostility and violence) against certain social or demographic groups, such as defending, threatening words, or encouraging acts of violence. This definition is sometimes extended to expressions that foster a climate of prejudice and intolerance that is assumed to fuel discrimination, hostility and attacks. In addition, citing the definition given by the Council of Europe (Weber, 2009), that hate speech includes all forms of expression that are spread to incite, promote or justify racial hatred, xenophobia, anti-Semitism, or other forms of hatred rooted in intolerance, including intolerance expressed nationalism and aggressive ethnocentrism, discrimination and hostility towards minorities and immigrants. In fact, in general language, the definition of hate speech tends to expand, sometimes even including words that insult the government or the individual. Especially at crucial times, such as during elections, hate speeches are vulnerable to manipulation. Politicians attack each other by spreading hate speech to seize and maintain power (Santoso, 2016; 88).

An interesting thing about this hate speech is that there is currently no definition of hate speech that is universally acceptable (Weber, 2015: 3). In Indonesia, there are at least two institutions that can be referred to understand the definition of hate speech. First, referring to Kaplori (Head of Indonesian Police Department) Circular Letter Number: SE / 6 / X / 2015 concerning hate speech that what is meant by hate speech is the whole act of being insulting, defaming, blasphemous, unpleasant actions, provoking, inciting or spreading false news (see also Mangantibe, 2016). Based on Head of Indonesian Police Department (Kapolri) circular letter Number: SE / 6 / X / 2015 concerning acts of spreading hate speech can be done through various media, including: 1. Speeches on campaign activities, 2. Banner, 3. Social media networks, 4. Public opinion (demonstration), 5. Religious discourses, 6. Print and electronic mass media,7. Pamphlets.

Second, the definition proposed by the Commission on Human Rights of the Republic of Indonesia that what is meant by hate speech is all actions and efforts, both directly 
and indirectly based on hatred on the basis of ethnicity, religion, beliefs, race, class, skin color, ethnicity, gender, people with disabilities, and sexual orientation which are incitement to individuals and groups that may result in discrimination, violence, loss of life and / or social conflict occur through various means (Komnas HAM, 2016).

The absence of universally acceptable definitions proves that cases of hate speech have a serious impact, and the practice is difficult to identify. The difficulty of identifying acts of hate speech is that the utterance of hatred does not always manifest through expressions of hatred or emotion. Speeches of hatred are often implied in statements that are considered normal even if observed, there are points that are considered hate speeches, especially for victims or targets of this action.

In a report on the results of a crime seminar conducted by the United States Holocaust Memorial Museum in 2009, entitled "Hate Speech and Group-Targeted Violence; The Role of Speech in Violent Conflicts "proposes a suggestion to consider the "speech context" in interpreting a case of hate speech. According to the report, it is very important to consider who delivered the hate speech, the intent of the statement, and to whom the statement was delivered. This is important because hate speech as a language includes inciting, insulting, vilifying, and a call to violence that targets certain individuals or groups.

Specifically, related to the "context" mentioned above, Gagliardone (2014) proposes that in order to analyze hate speech, we can use a critical discourse analysis approach that emphasizes the role of the social context in the analysis of a text. For him, utterances of hatred are texts that always relate to context. For example, in political speech, it is not uncommon for politicians to show their power by discriminating against certain ethnicities and races. So that through the text of his speech, politicians may hide certain agendas, interests and ideologies.

The same thing was expressed by Özarslan (2014) who stated that the speech act theory can be applied in analyzing hate speech. According to him, the concept of speech act stated by Austin (1962) that when someone says something, he also does something, including doing acts of hate speech, always bound by social and cultural contexts. Such application is referred to as "hate speech act" (compare with Virginia and Olenrewaju, 2017). Based on the opinions of Gagliardone (2014) and Özarslan (2014) above, this article attempts to describe the role of critical discourse analysis and speech act theory in analyzing hate speech as linguistic phenomena. 


\section{Literature Review}

It has been stated above that hate speech can be interpreted as words, behaviors, and writings carried out by individuals or groups in the form of provocation, incitement or insult to other individuals or groups. Hate speech usually touches many aspects ranging from race, color, ethnicity, gender, disability, sexual orientation, citizenship, to religion and others (Teja, 2017). Moving on from this kind of understanding, it can be said that all expressions of hate speech are realized through both verbal and nonverbal language that aims to discriminate, intimidate, dominate and create hostility and violence.

In harmony with the above, language is a reflection of its users. In other words, Ianguage reflects a person's personality, even a mirror of the personality and of a national culture. Experts argue that language has various functions including transactional and interactional functions (see Siregar, 2011: 137). According to him, transaction function is a function of language to express the statement which includes the disclosure of ideas, thoughts, feelings, desires and attitudes and factual information. Interactional function of language is the use of language to create and maintain certain social relations that are aimed at building the success of interpersonal relationships, both in the context of the group and the context between groups in a particular society.

In everyday life people use language to do something or influence others to do something which is commonly known as the speech act (compare with others, Tarigan, 1990: 145; Griffiths, 2006:148; Brasdefer, 2014: 323;). In the context of community life that upholds the meaning of diversity, of course the use of language is always intended to keep social relations more harmonious, peaceful and tolerant. Language can also reflect violence. Not physical violence but verbal violence that tends to represent power (read, Baryadi, 2012). Furthermore, Baryadi (2012) suggests that verbal violence or language violence is violence that uses language, namely violence that uses words, sentences and other language elements.

As a social action, the speech act is also the act of the speaker positioning himself in social relations with the speech partner, whether equal, higher or lower. Therefore a speech can contain different intentions when used in different contexts. Based on its suitability with social objectives, Leech (1993) distinguishes speech acts into four types, namely (1) conflictive speech acts, (2) competitive speech acts, (3) collaborative speech acts, (4) convivial speech acts. In this case, the social purpose of speaking is to create a harmonious relationship between speakers and partners. Based on the distinction of the four types of speech acts, the conflictive speech acts tend to lead to acts of hate speech (check Baryadi, 2012). So that it can be said that hate speech can be acts of language 
violence or vice versa that acts of language violence can be acts of hate speech. The reason is that conflictive speech acts as proposed by Leech (1993) are speeches that can cause hostility, social conflict and physical violence, for example threatening, accusing, railing, mocking, yelling, rebuking, challenging, swearing, inciting, vilifying, insulting, cursing, belittling, criticizing, and urging (read Baryadi, 2012: 32).

\subsection{Context and hate speech}

It has been mentioned above, that to analyze hate speech, we can use critical discourse analysis and speech act theory, because both consider the context in analyzing linguistic data. Therefore in this section we will describe the context in understanding acts of hate speech based on a critical discourse analysis approach and speech act theory.

Citing Eriyanto (2001) who states that critical discourse analysis considers the context of discourse, such as background, situation, events, and conditions. The discourse is seen as being produced, understood, and analyzed in a particular context. Following Guy and Cook, discourse analysis also examines the context of communication: who communicates with whom and why; in what kind of audience and situation; through what medium; how the different types of communication develop, and relationships for each party. The starting point of discourse analysis is, language cannot be understood as an internal mechanism of linguistics alone, not an object isolated in a closed space. Language is understood in the overall context. Guy and Cook say there are three pivotal things in the notion of discourse: text, context, and discourse. Text is all forms of language, not only the words printed on the sheet, but also all kinds of expressions of communication, speech, music, pictures, sound effects, images and so on. Context includes all situations and things that are outside the text and affect the use of language, such as participants in language, situations in which the text is produced, functions intended, and so on. The discourse here is then interpreted as text and context together. The focus of discourse analysis is to describe text and context together in a communication process. Here, it is needed not only the process of cognition in the general sense, but also the specific description of the culture carried. The study of language, includes context, because language is always in context, and there is no action for communication without participants, inter text, situations, and so on.

Discourse is not considered as a constant area, occurs anywhere and anytime, in any situation. Discourse is formed and must be interpreted in special conditions and situations. Critical discourse defines text and conversation in certain situations, discourse is in certain social situations. However, not all contexts are included in the 
analysis, only those that are relevant and in many ways influence the production and interpretation of the text included in the analysis. There are several important contexts because they influence the production of discourse. First, discourse participants who produce discourse. Gender, age, education, social class, ethnicity, religion, are in many respects relevant in describing discourse. For example, someone speaks in a certain domains because he is male, or because he is educated. Second, social settings, such as place, time, position of speaker and listener or physical environment are contexts that are useful for understanding a discourse. For example, the conversation at the college is different from on the road, the conversation in the office is different from the conversation in the canteen. Settings, such as those that are private or public, in a formal or informal setting, or in certain spaces provide certain discourses. Speaking in a courtroom is different from talking in the marketplace, or talking at home is different from talking in a classroom, because social situations and rules that surround it are different, causing communication participants to adjust to the context. Therefore, discourse must be understood and interpreted from the conditions and the underlying social environment.

Another language study that considers context is the study of speech acts. Speech acts are part of the pragmatic study. Pragmatics as a branch of linguistics studies the structure of language externally or how the linguistic unit is used in communication. Wijana and Rohmadi, (2010: 4) say that pragmatics is a branch of linguistics that examines the meanings of lingual units, externally. The pragmatic meaning examines context-bound meanings. Here the context is understood as background knowledge that is shared by speakers, so that speakers understand what is meant by their counter parts (see Leech, 1983: 13; Akmajian et al, 2001: 388; Cutting, 2002: 5; Cruse, 2006: 35; Kridalaksana, 2008, 134; Holmes \& Stubbe, 2015: 9). But to Cutting (2002: 52) that the context correlates with differences in status, age, gender, education, social class, position, and ethnicity.

The speech act was first delivered by John L. Austin in his work entitled "How To Do Things With Words". According to him (1962: 94) when someone said something, he also did something. That what he calls speech act. At least according to Austin (1962: 94-101) there are three types of speech acts, namely locution, illocutionary and perlocution.

Locutions are the act of saying something (1962: 94). For him locutionary acts are at the basic level of speech acts, to understand them we need to understand phonology, syntax and semantics. In other words, it can be said that locution is the basic meaning or reference of the speech. For example, the following utterance (1):

1. Someone won two gold medals. (Griffiths, 2006: 15) 
Example (1) can be interpreted only as a statement that someone has won two medals. In this utterance the speaker does not have any intended meaning solely just to inform something without any intention to do something.

llocutionary speech acts are doing an action in saying something (the act in saying something) (1962: 99). Illocutionary force is a propositional content in illocutionary speech acts. For example, utterance (1) can have different propositions in certain contexts. To prove this, utterance (1) is abbreviated to be 'sw2gm' (Griffiths, 2006: 15).

1. "Someone won two gold medals" - is a statement by the speaker expressing the commitment on the assumption that the speaker is not at all and does not yet know that "sw2gm".

2. "Who won two gold medals?" - is a question that intends to ask for the identity of "sw2gm" that you want to know.

3. "Who won two gold medals?" - is a compliment made by the winner's mother. With that utterance the mother gives the opportunity to "sw2gm" say "I did"

4. "Who won two gold medals?" - is a speech that expresses the pride of "sw2gm" in front of the audience.

5. "Be the one who wins two gold medals!" - is a command by a coach to the athletes to become "sw2gm".

Based on the five illustrations above, it can be seen that the power of the illocutionary speech acts has different purposes, depending on the context of speech. In other words, illocutionary speech acts may cause different powers as meant by the speaker and can mean to express, praise, ask, boast, command.

Perlocutions are the acts by saying something to influence feelings, thoughts and actions (the act by saying something) (1962: 101). In other words, perlocution is the result of illocutionary speech acts. For example, utterance (1a) can make the speaker know, (1b) makes the speaker give answers, (1c) makes the speaker feel happy.

\section{Research Method}

The method used in this paper is descriptive qualitative. This research method aims to describe, summarize various conditions, various situations, or various phenomena of social reality. The study also attempts to draw the reality to the surface as a characteristic, character, trait, model, sign, or description of a particular condition, situation, or phenomenon (Bungin, 2017). 
The data are utterances or speech in the form of words, phrases and sentences. The data are from the utterances or speech of the members and net citizens in the Facebook group account Kombur- Kombur Pilkada Batu Bara 2018 Menuju Masyarakat Ekonomi $\mathrm{Bb}$ Bersinar (Towards the prosperity of Batu Bara) and Facebook group account KomburKombur Pilkada Batubara 2018. Data collected using the refer method (Sudaryanto, 2015). This method is used to observe the speech of net citizen's hatred on issues related to the social, cultural and political background of each candidate. The technique of record is used to record the expression of hate speech by the net citizens (Sudaryanto, 2015).

The data collected then analyzed using contextual analysis method (Rahardi, 2009). A contextual analysis is simply an analysis of a text (in whatever medium, including multimedia) that helps us to assess that text within the context of its historical and cultural setting, but also in terms of its textuality - or the qualities that characterize the text as a text. The context referred to in this method is the language environment. Linguistic environment may be physical environment or nonphysical environment. In other words the context can be understood as the background knowledge shared by speakers and hearers, so the hearers understand what the speakers mean (Leech, 1983).

\section{Result and Discussion}

The following describes how the phenomenon of hate speech can be observed and analyzed using a pragmatic approach, especially the study of speech acts. First of all, to be able to apply the theory of speech acts is to know the illocutionary classification as suggested by Searle (1969). The proposed classification is based on the three main principles, namely, (1) illocutionary point or illocutionary meaning uttered by speakers, (2) words adapted to world of reality (direction of fit), (3) psychologically expressed with sincerity (psychological states/ sincerity condition).

TABLE 1: Searle's Classification of Speech Acts (adapted from Yule, 1996).

Speech act type
Assertives
Commissives
Directives
Declarations
Expressives

Direction of fit
make words fit the world
make the world fit words
make the world fit words
word changes the world
make words fit the world

$\mathrm{S}=$ Speaker

$\mathrm{X}=$ Situation

S believes $X$

S intends $X$

S wants $X$

S causes $X$

$S$ feels $X$ 
Searle has also proposed the idea that the realization of the use of speech acts is influenced by four conditions which he then calls constitutive rules of a speech act, namely (1) the condition of the contents of the proposition, (2) the conditions of preparation, (3) the condition of sincerity, and (4) essential conditions. According to him, each of these conditions can distinguish the intent of each form of speech acts from one another. There are five illocutionary classifications proposed by Searle (1979), namely: 1. Assertives: speech acts that involve speakers on the propositional truth expressed. 2. Directive: speech act that is intended by the speaker to make the listener does something. 3. Commissive: is a speech act that binds speakers to an action that will be done in the future. 4. Expressive: is a speech act that expresses the psychological attitudes of speakers to a situation. 5. Declarations: are illocutionary acts which if the performance is successful will cause good correspondence between the propositional contents to reality.

For the sake of this study, an example of utterance quoted from Facebook group account that occurred during the local election in Batu Bara, it goes as follows:

1. 'Cino dah makin merajolela di Indonesia ini diseluruh penjurunyo'

(Chinese has become more and more rampant in Indonesia throughout the entire country $[\ldots](\mathrm{HS} .01))$

To analyze it, we have to determine initially, the type of illocutionary speech act from HS 1 that is by applying the rules of speech constituted as shown in the table below,

TABLE 2: Illocutionary assertive acts.

\begin{tabular}{|c|c|}
\hline \multicolumn{2}{|r|}{ Illocutionary Assertive Act } \\
\hline Propositional content & $\begin{array}{l}\text { truth of the information, experience and evidence that Chinese } \\
\text { descendants try to dominate Indonesia (Pc) }\end{array}$ \\
\hline \multirow[t]{2}{*}{ Preparatory } & 1. Speaker (S) has facts, reasons, evidences on Pc \\
\hline & 2. Hearer has no clear reasons on $\mathrm{Pc}$ \\
\hline Sincerity & Speaker believes Pc \\
\hline Essential & Pc shows that the information is true \\
\hline
\end{tabular}

There are two sub types of assertive found in this case, namely;

a. Statement. This sub type indicates the speaker's belief in stating something. There are two aims of this sub type, to state and to inform. The parameter of this category is when the speaker speaks, the speaker states that the Proposition is: i). stating that there is information, ii). experience and iii). evidence that he believes that Chinese is an ethnic who is trying to dominate Indonesia in any way. The explanation of this sub-type can be seen as follows, 
(1) Cino dah makin merajolela di Indonesia ini diseluruh penjurunyo 'Chinese are rampant all over Indonesia'. The utterance (1) is sub type statement of assertive.

Through the utterance (1) speaker tries to declare that Chinese in Indonesia are trying to dominate Indonesia. It seems that this prejudice arose after the presidential election of Indonesia in 2014. It continued after the act to protect Islam against defamation I, II, and III which asked the government to punish Basuki Tjahaja Purnama who had defamed Islam. Meanwhile, the news of a large wave of foreign workers from the People's Republic of China (PRC) is increasingly leads to situations and sentiments between ethnics and religions in Indonesia. One way to think about the speech acts being performed via utterances is to assume that underlying every utterance $(U)$ there is a clause, containing a performative verb (Vp) which makes the illocutionary force explicit (Austin, 1962). This is known as performative hypothesis and the basic format of the underlying clause is ' (hereby) Vp you (that) U' (Yule, 1996). Applying paraphrase technique as proposed by Sudaryanto (2015) on hate speech (1) the true aim of statement of assertive sub type can be exercised, "I hereby \{state/ inform\} you that Chinese are rampant all over Indonesia".

b. Prediction. This sub-type predicts what will happen in the future based on the speaker's belief. The parameter of this sub type is when speaker utters the speech, the speaker predicts the Proposition $(\mathrm{Pc})$ : i). Predicting that something will happen as evidence that the information, experience and evidence of ethnic Chinese ambition that he has is true. Explanation of this sub-type can also be seen in the following utterance,

(2) Kojap lagi Indonesia pun menjadi Negara Cina ‘

(In the near future Indonesia will become China)(HS 2).

The sub-type truth can be tested by the performative hypothesis and paraphrase technique as described earlier. Consider the following illustration: (2) I hereby \{predict that in the near future Indonesia will become China.

Based on the above paraphrase technique, it can be said that utterance (2) is an assertive of predicting sub-type, the speaker intended to predict what would happen if the Chinese and the foreign workers from China had succeeded in carrying out Indonesia.

Based on the explanation above, it can be concluded that utterances (1) and (2) are provoking hate speeches. With these utterances, the speaker provoked listeners to stop Chinese ethnic hegemony in Indonesia by all means. In turn, the utterances can lead to physical violence. It also proves that the pragmatic approach especially the speech act theory can be applied to analyze whether an utterance contains elements of hate speech or not. 


\section{Conclusions}

The problems faced by the Indonesian people today are very complex and can threaten the integrity of the nation. Issues that could threaten the unity and integrity of the republic do not only come from differences in political attitudes and certain ideologies. But it can also originate from acts of hate speech. On the other hand, the emergence of discussions about acts of hate speech actually gives a new object of study for linguistic development in Indonesia. Based on the linguistic perspective, hate speech is a phenomenon of offensive language that can present linguistic data and can be analyzed linguistically. The connection of hate speech with the context of speech opens up opportunities for linguists to take positions and roles in solving cases related to the spread of hatred. The application of critical discourse analysis and pragmatics, especially speech act theory is expected to solve the problem of linguistically spreading hate speech so it has implications for fair law enforcement.

\section{Acknowledgements}

The authors gratefully acknowledge that the present research is supported by Ministry of Research and Technology and Higher Education Republic of Indonesia. The support is under research grant DRPM of year 2019 contract number: 11/E1/KP.PTNBH/2019,March 29,2019

\section{References}

[1] Ahnaf, M. Iqbal dan Suhadi. (2015). Isu-Isu Kunci Ujaran Kebencian (Hate Speech): Implikasinya Terhadap Gerakan Sosial Membangun Toleransi. Harmoni: Jurnal Multikultur Multireligius.

[2] Akmajian, Adrian, dkk. (2001). Linguistics: An Introduction to Language and Communication. Fourth Edition. Cambridge: Cambridge University Press.

[3] Austin, J.L. 1962. How to Do Things With Words. London: Cambridge University Press.

[4] Brasdefer, J. Cesar Felix. (2014). "Speech Act Sequences" dalam Bublitz, Wolfram, dkk, Handbooks of Pragmatics. Berlin/Boston: De Gruyter Mouton

[5] Baryadi, Praptomo.(2012). Bahasa, Kekuasaan, dan Kekerasan. Yokyakarta: University Sanata Dharma. 
[6] Bublitz, Wolfram, dkk. (2014). Handbooks of Pragmatics. Berlin/Boston: De Gruyter Mouton.

[7] Cutting, Joan. (2002). Pragmatics and Discourse. London. Routledge.

[8] Cruse, Alan. (2006). A Glossary of Semantics and Pragmatics. Edinburgh: Edinburgh University Press.

[9] Ezeibe, Christian Chukwuebuka dan Okey Marcellus Ikeanyibe. Ethnic Politics, Hate Speech, And Acces To Political Power In Nigeria. Africa Today. 63 (4). 65-83.

[10] Gagliardone, Ignio, dkk. (2014). Mapping And Analysing Hate Speech Online: Opportunities and Challenges for Ethiopia. Oxford.

[11] Griffiths, Patrick. (2006). An Introduction to English Semantics and Pragmatics. Edinburgh: Edinburgh University Press.

[12] Holmes, Janet dan Maria Stubbe. (2015). Power and Politeness in the Workplace: a Sociolingusitic Analysis of Talk at Work. New York: Routledge.

[13] Imparsial, (2017). Penebaran Kebencian: Masalah Pengaturan dan Penanganannya. Jakarta: IMPARSIAL, The Indonesian Human Rights Monitor.

[14] Kepolisian Negara Republik Indonesia. (2015). Surat Edaran Nomor:SE/6/X/2015. Jakarta.

[15] Komisi Nasional Hak Asasi Manusia Republik Indonesia. (2016). Buku Saku Penanganan Ujaran Kebencian (Hate Speech). Jakarta.

[16] Kridalaksana, Harimurti. (2008). Kamus Linguistik. Jakarta: Gramedia.

[17] Leech, Geofrey. (1983).Priciples of Pragmatics. New York: Longman.

[18] Mangantibe, Vaesy. (2016). Ujaran Kebencian Dalam Surat Edaran Kapolri Nomor: SE/6/X/2015 Tentang Penanganan Ucapan Kebencian (Hate Speech). Jurnal Lex Crimen [online], Volume 5 (1), p. 159-162.

[19] Retrieved from https://ejournal.unsrat.ac.id/index.php/lexcrimen/article/view/10614.

[20] Özarslan, Zeynep. (2014). Introducing Two New Terms Into The Literature of Hate Speech: "Hate Discourse" And "Hate Speech Act" Application of "Speech Act Theory" Into Hate Speech Studies in The Era of Web 2.0. Haziran. (20). 53-75.

[21] Rongiyati, Sulasi. (2015). Surat Edaran Kapolri Tentang Ujaran Kebencian: Menjaga Kebebasan Berpendapat Dan Harmonisasi Kemajemukan. Info Singkat, Vol.II, No.21.

[22] Santoso, Edi.(2016). Pengendalian Pesan Kebencian (Hate Speech) Di Media Baru Melalui Peningkatan Literasi Media. Proceedings of National Conference on Communication. Retrieved from http://jurnal.fisip.unila.ac.id/index.php/prosidingkom/ article/viewFile/274/175. 
[23] Searle, John R. (1969). Speech Acts an Essay in The Philosophy of Language. Cambridge. Cambridge University Press.

[24] Searle, John R. (1979). Expression and Meaning: Studies in The Theory of Speech Act. Cambridge: Cambridge University Press.

[25] Sihombing, Benedictus A. (2016). Ujaran Kebencian Membangun Literasi Era Digital. Proceeding International Conference Of Communication, Industry And Community (pp 105 - 113). Jakarta.

[26] Siregar, Bahren Umar.(2011) Seluk-Beluk Fungsi Bahasa. Jakarta: Pusat Kajian Bahasa dan Budaya Universitas Katolik Indonesia Atma Jaya.

[27] Tarigan, Henry Guntur. (1990). Pengajaran Pragmatik. Bandung: Angkasa.

[28] Teja, Mohammad. (2017). Media Sosial: Ujaran kebencian Dan Persekusi. Info Singkat. IX (11). 9-12.

[29] Townsend, Emma. (2014). Hate Speech or Genocidal Discourse? An Examination of Anti-Roma Sentiment in Contemporary Europe. Portal. 11 (1). 1-23.

[30] Virginia, Okafor C dan Alabit Taofeek Olanrewaju. (2017). A Speech Act Analysis Of Hate Speeches In The 2015 General Election Campaign In Nigeria. IMPACT: Internasional Journal of Research In Humanities, Arts and Literature. 5 (6). 61-72.

[31] Weber, Anne. (2009). Manual On Hate Speech. Council Of Europe.

[32] Yule, George. (2006). Pragmatik. Yogyakarta: Pustaka Pelajar. 